\title{
Implementasi PERMENDIKNAS NO. 28 Tahun 2010 Tentang Penugasan Guru Sebagai Kepala Sekolah Pada Sekolah Menengah Pertama di Kabupaten Bima Nusa Tenggara Barat.
}

\author{
Ilham \\ Email : $\underline{\text { ilhamfis58@gmail.com }}$
}

\begin{abstract}
Abstrak : Tujuan dari penelitian ini mengetahui; (1) Mekanisme perekrutan calon kepala sekolah di Kabupaten Bima Nusa Tenggara Barat; (2) Proses pengangkatan kepala sekolah di Kabupaten Bima Nusa Tenggara Barat; (3) Faktor pendukung dan penghambat implementasi Permendiknas No. 28 Tahun 2010 di Kabupaten Bima Nusa Tenggara Barat; (4) Upaya mengatasi faktor penghambat implementasi Permendiknas No.28 Tahun 2010. Jenis penelitian deskriptif pendekatan kualitatif. Lokasi Penelitian Dikpora, BKD dan SMP di Kabupaten Bima Nusa Tenggara Barat. Jenis data; data primer dan sekunder. Subjek penelitian Kasi KPMP Dikmen, Kepala Mutasi BKD, dan Kepala Sekolah. Instrumen, peniliti sendiri. Pengumpalan data, dengan observasi, wawancara dan dokumentasi. Analisis melalui Reduksi data, Penyajian data, Penarikan kesimpulan. Pengecekan keabsahan data melalui teknik; triangulasi sumber dan teknik pengumpulan data. Hasil dan kesimpulan; 1) Mekanisme perekrutan Cakep Menengah Pertama di Kabupaten Bima Nusa Tenggara Barat melalui empat tahap. Pertama, pengumuman oleh Dikpora. Kedua, pengusulan oleh kepala sekolah. Ketiga, seleksi administrasi. Keempat, pengusulan oleh Dikpora, melalui Jalur umum, cakep diusulkan berdasarkan pengusulan kepala sekolah dan pengawas. Sedangkan jalur khusus, cakep langsung ditetapkan oleh Dikpora dan Bupati. 2) Proses pengangkatan kepala sekolah di Kabupaten Bima Nusa Tenggara Barat berdasar Permendiknas No.28 Tahun 2010, pengangkatan secara definitif dan PP No.100 Tahun 2000, pengangkatan sebagai pelaksana tugas (Plt). 3) Faktor penghambat penerapan Permendiknas No. 28 Tahun 2010 yaitu, Dikpora belum menerapkan secara keseluruhan isi Permendiknas disebabkan sukar memahaminya, adanya politisasi jabatan yang dilakukan oleh Bupati. Sedangkan faktor pendukung bertambahnya antusias guru yang ditandai dengan bertambahnya cakep yang berkualifikasi S2 setiap tahun mengikuti tes cakep. 4) Upaya mengatasi faktor penghambat, Dikpora menyesuaikan penerapan Permendiknas No.28 Tahun 2010 dengan Permendiknas No.13 Tahun 2007 dalam proses perekrutan dan pengangkatan kepala sekolah di Kabupaten Bima Nusa Tenggara Barat dengan memberikan keringan kepada calon kepala sekolah terkait kelengkapan administrasi. Upaya yang dilakukan terhadap pengangkatan kepala sekolah yang ditunjuk langsung oleh Bupati yang berstatus Plt, tidak ditugaskan pada sekolah Negeri, BKD menempatkan pada sekolah SATAP.
\end{abstract}

Kata Kunci: Implementasi, Mekanisme Perekrutan, Proses Pengangkatan, Tugas Guru Sebagai Kepala Sekolah.

Abstract: The purpose of this study is to find out; (1) Mechanism for recruiting prospective principals in Bima Regency, West Nusa Tenggara; (2) The process of appointing school principals in Bima Regency, West Nusa Tenggara; (3) Supporting factors and obstacles to the implementation of Permendiknas No. 28 of 2010 in the Regency of Bima, West Nusa Tenggara; (4) Efforts to overcome the inhibiting factors of the implementation of Permendiknas No.28 of 2010. This type of research is a qualitative descriptive approach. Dikpora, BKD and SMP research locations in Bima Regency, West Nusa Tenggara. Data type; primary and secondary data. The research subjects were Kasi KPMP Dikmen, BKD Mutation Head, and School Principal. Instruments, researchers themselves. Data collection, with observation, interview and documentation. Analysis through data reduction, data presentation, drawing conclusions. Checking the validity of the data through techniques; source triangulation and data collection techniques. 
Results and conclusions; 1) The mechanism for the recruitment of First Intermediate Cakep in Bima Regency, West Nusa Tenggara through four stages. First, the announcement by Dikpora. Second, the proposal by the principal. Third, administrative selection. Fourth, proposals by Dikpora, through public channels, are cute based on the proposals of school principals and supervisors. Whereas the special lane, the saucy is directly determined by the Dikpora and the Regent. 2) The process of appointing school principals in Bima Regency, West Nusa Tenggara based on Ministry of Education Regulation No.28 of 2010, definitive appointment and PP No.100 of 2000, appointment as task executor (Acting). 3) Factors inhibiting the application of Permendiknas No. 28 of 2010 that is, Dikpora has not implemented the entire contents of Permendiknas because it is difficult to understand, the politicization of positions conducted by the Regent. While the supporting factor is the increasing enthusiasm of teachers, which is indicated by the increasing number of graduated cakep who qualify for S2 every year taking a cakep test. 4) Efforts to overcome the inhibiting factors, Dikpora adjusts the application of Permendiknas No.28 of 2010 with Permendiknas No.13 of 2007 in the process of recruiting and appointing principals in Bima Regency, West Nusa Tenggara by providing relief for prospective principals regarding administrative completeness. Efforts made on the appointment of the school principal who was appointed directly by the Bupati with the status of Plt, were not assigned to the State school, BKD placed the SATAP school.

Keywords: Implementation, Recruitment Mechanisms, Appointment Process, Teachers' Assignments As Principal.

\section{PENDAHULUAN}

Kebijakan Otonomi Daerah diatur dalam UU Nomor 32 Tahun 2004 tentang Pemerintahan Daerah. Sebagaimana dijelaskan dalam Pasal 1 Butir 5, yaitu : "hak, wewenang dan kewajiban Daerah Otonom untuk mengatur dan mengurus sendiri urusan pemerintahan dan kepentingan masyarakat setempat sesuai dengan peraturan perundangundangan". Penyelenggaraan Otonomi Daerah tersebut ada tiga bentuk penyerahan wewenang, yaitu Desentralisasi, Dekonsentrasi dan tugas Pembantuan. Misalnya mengenai pengangkatan, pemindahan dan pemberhentian dari dan dalam jabatan untuk eselon II di daerah Provinsi ditetapkan oleh Gubernur, sementara di tingkat Kabupaten/Kota ditetapkan oleh Bupati/Walikota setelah berkonsultasi dengan Gubernur (Rahmawiati E, dkk. 2009).

Sedangkan pada jabatan struktural dalam hal ini pengangkatan kepala sekolah secara Pltpun ikut terkontaminsasi oleh politik praktis pemerintah daerah, tidak disiasati berdasarkan PP No.100 Tahun 2000, namun berdasarkan asas spoils yaitu penempatan kerabat sealairan politik dalam jabatan-jabatan strategis dan dinilai berdasarkan kinerja non akademik yaitu penghargaan yang diberikan pada seorang guru karena pernah mengadakan dan membangunan lembaga pendidikan.

Berdasarkan hasil wawancara pra penelitian bahwa pengangkatan yang berasas spoils dan penilaian kinerja non akademik diberlakukan dibeberapa sekolah di Kabupaten Bima Nusa Tenggara Barat salah satunya pengangkatan Kepala SMPN 4 Donggo. Hal ini sejalan dengan pendapatnya Nurlinah bahwa pengangkatan PNS dalam jabatan struktural yang dilakukan oleh Walikota Makassar akhir-akhir ini, kerap ditemukan praktek "spoils" yaitu penempatan kerabat sealiran politik dalam jabatan-jabatan strategis di birokrasi pemerintahan (Nurlinah, 2016).

Pembaharuan sistem pendidikan sebagai upaya meningkatkan mutu pendidikan nasional. Lahirnya Undang-Undang Sistem Pendidikan Nasional tahun 2003, Undangundang no. 14 tahun 2005 tentang guru dan dosen, Peraturan Menteri No. 19 tahun 2005 tentang standar Nasional Pendidikan, dan Permendiknas No. 12 tahun 2007 tentang standar pengawas Sekolah, serta Permendiknas No.28 Tahun 2010 tentang penugasan guru sebagai kepala sekolah pada dasarnya merupakan kebijakan pemerintah yang memuat usaha pemerintah untuk menata 
dan memprediksi mutu pendidikan Indonesia (Bhirowaty, 2014).

Buruknya kualitas pendidikan tidak terlepas dari buruknya kualitas pelayanan pendidikan. Baswedan (2014) memaparkan buruknya kualitas layanan pendidikan di Indonesia dalam tulisannya "Gawat darurat pendidikan di Indonesia". Ia menjelaskan tentang bagaimana potret buruknya kualitas layanan pendidikan seperti; (1) 75 persen sekolah di Indonesia tidak memenuhi standar layanan minimal pendidikan ; (2) Nilai ratarata uji kompetensi guru 44,5, standar nilai yang harapkan 70; (3) Indonesia menjadi peringkat 103 dunia, Negara yang di dunia pendidikannya diwarnai aksi suap menyuap dan pungutan liar.

$$
\text { Upaya memperbaiki lembaga }
$$

pendidikan dimulai dari memperbaiki birokratnya yaitu dimulai dari kepala sekolah (Maisaroh, 2015). Secara operasional, kepala sekolah adalah orang yang berada digaris terdepan yang mengkoordinasikan pembelajaran yang bermutu. Wahjosumidjo (2008) mengatakan kunci keberhasilan suatu sekolah terletak pada efisiensi dan efektivitas penampilan seorang kepala sekolah. Disamping itu juga melalui Permendiknas Nomor 28 tahun 2010 pasal 3 bahwa Penyiapan calon kepala sekolah meliputi rekruitmen serta pendidikan dan pelatihan calon kepala sekolah pemerintah Kabupaten melalui dinas pendidikan akan mendapatkan kepala sekolah yang handal, profesional, memiliki visi dan misi yang mampu mengakomodasi perkembangan ilmu pengetahuan dan teknologi menuju sekolah yang berkualitas (Muliati, 2013).

Berdasarkan hasil penelitian yang dilakukan oleh Baihaqi dan kawan-kawan (2012) tentang Sistem Rekrutmen, Seleksi dan Penempatan Kepala Sekolah Menengah Pertama Negeri Pada Dinas Pendidikan Kota Banda Aceh menunjukan bahwa dari 16 orang yang mengikuti proses rekrutmen kepala Sekolah Menengah Pertama yang dinyatakan lulus diklat berjumlah 11 orang peserta. Hasil wawancara yang lakukan dengan salah seorang guru calon kepala sekolah yang mengatakan bahwa proses seleksi tidak dilakukan secara terbuka, seperti, skor hasil tes, baik berupa tes tulis dan wawancara. Hasil penelitian yang dilakukan oleh Wahiyuddin (2014) tentang Politisasi Pejabat Struktural Eselon II di Lingkungan Sekretariat Daerah Kabupaten Muna Sulawesi Tengggara menunjukan bahwa rekrutmen, pengangkatan dan pemindahan serta pembinaan karir PNS sangat tidak memperhatikan prinsip kompetensi akan tetapi didasarkan pada pertimbangan politik.

Mencermati tentang mutu kepala sekolah, berdasarkan laporan Bank Dunia (1999), bahwa menurunnya mutu pendidikan persekolahan di Indonesia disebabkan masih rendahnya tingkat profesionalisme kepala sekolah sebagai manajer pendidikan di tingkat lapangan. Rendahnya profesionalisme di antaranya karena masih lemahnya di dalam cara pengangkatan kepala sekolah. Sejalan dengan pendapat Mulyasa (2003), bahwa pengangkatannya tidak berdasarkan pada kemampuan dan pendidikan profesional, tetapi lebih mengedepankan cara pengangkatan dilihat dari kepangkatan dan pengalaman menjadi guru.

Pembahasan singkat di atas terkait tentang Implementasi PERMENDIKNAS NO. 28 Tahun 2010 Tentang Penugasan Guru Sebagai Kepala Sekolah Pada Sekolah Menengah Pertama di Kabupaten Bima Nusa Tenggara Barat. Maka rumusan masalah sebagai berikut: (1) Bagaimana mekanisme perekrutan calon kepala Sekolah Menengah Pertama di Kabupaten Bima Nusa Tenggara Barat? (2) Bagaimana proses pengangkatan Kepala Sekolah Menengah Pertama di Kabupaten Bima Nusa Tenggara Barat? (3) Faktor pendukung dan penghambat implementasi PERMENDIKNAS NO. 28 Tahun 2010 di Kabupaten Bima Nusa Tenggara Barat? (4) Upaya mengatasi hambatan implementasi Permendiknas No.28 Tahun 2010 di Kabupaten Bima Nusa Tenggara Barat.

\section{KAJIAN PUSTAKA}

1. Permendiknas No.28 Tahun 2010

Permendiknas No. 28 tahun 2010 tentang Penugasan Guru sebagai Kepala Sekolah berlaku untuk mutasi kapala sekolah pada jenjang TK/RA, SD/MI, SMP/MTs, 
SMA/MA, dan SMK. Tidak terkecuali rintisan sekolah bertaraf internasional (RSBI). Menurut Nuh, penyiapan calon kapala sekolah wajib mengikuti berbagai seleksi ketat.

Dirjen Peningkatan Mutu Pendidik dan Tenaga Kependidikan (Ditjen PMPTK) Baedhowi menegaskan, proses pengangkatan kepala sekolah perlu melalui penilaian akseptabilitas oleh tim pertimbangan pengangkatan yang ditetapkan oleh pemerintah, pemerintah provinsi, pemerintah kabupaten/kota dan penyelenggara sekolah. Bahkan, para calon kapala sekolah juga akan diperkenalkan dengan lisensi yang menyatakan lulus kompetensi. Mereka yang berada di ruang lingkup pendidikan patut dilindungi dari politik praktis yang sering melibatkan kepala sekolah di dalamnya. Ada yang dicopot dari jabatan kapala sekolah tanpa alasan, ada juga yang dipindah di daerah terpencil juga tidak ada alasan (Nuh, 2010).

2. Tugas Tambahan Guru Sebagai Kepala Sekolah

Guru memiliki tugas tambahan struktural dan tugas tambahan fungsional. Tugas Fungsional yaitu tugas yang diberikan kepada guru yang memiliki kriteria-kriteria khusus yang dinilai berdasarkan kualifikasi pendidikan, kualifikasi kepangkatan dan status kepegawaian. Misalnya sebagai kepala sekolah, wakil kepala sekolah, kepala perpustakaan, kepala laboratorium, ketua jurusan dan lain-lain (Sudarsono, 2010).

3. Syarat guru menjadi Kepala Sekolah

Guru yang diangkat menjadi kepala sekolah harus memenuhi kriteria-kriteria yang disyaratkan yang mencakup kepribadian, keahlian dasar, pengalaman dan pengetahuan profesional, diklat dan keterampilan profesional, pengetahuan administrasi dan pengawasan. Wahjosumidjo (2011), menjelaskan guru sebagai kepala sekolah yang diberi tugas tambahan untuk memimpin lembaga sekolah (Nurbaya, 2015). Guru dapat diberi tugas tambahan sebagai kepala sekolah apabila memenuhi persyaratan umum dan persyaratan khusus, hal ini sebagaimana yang diatur dalam Permendiknas No.28 Tahun 2010 Bab II, Pasal 2 (terlampir).
4. Penyiapan calon Kepala Sekolah oleh Dinas Pendidikan Kabupaten/Kota

Berdasarkan ketentuan yang dimuat dalam Permendiknas No.28 Tahun 2010 bahwa dalam penugasan guru sebagai kepala sekolah harus dimulai dari tahap:

4.1.Penyiapan Kepala Sekolah

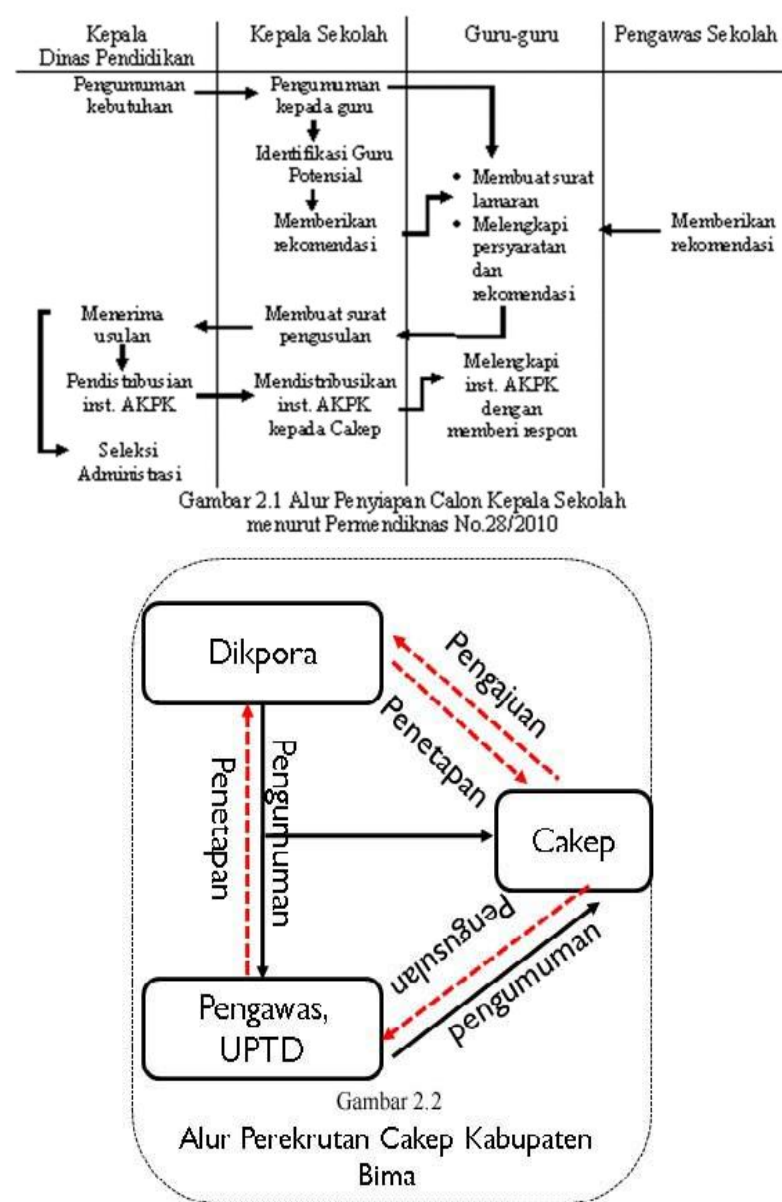

Berdasarkan gambar 2.1, proses penyiapan calon kepala sekolah mengikuti langkah-langkah: (a) Dinas Pendidikan membuat pengumuman, (b) Kepala Sekolah mengumumkan dan merekomendasikan guruguru untuk mengikuti tes calon kepala sekolah, (c) Guru membuat surat lamaran dan melengkapi persyaratan yang telah ditetapkan, (d) Pengawas sekolah memberikan rekomendasi kepada guru peserta seleksi calon kepala sekolah, (e) Kepala sekolah membuat usulan kepada kepala Dinas Pendidikan, (f) Dinas Pendidikan melakukan seleksi administrasi, dan mendistribusikan instrumen AKPK, (g) Kepala Sekolah yang diberi instrumen AKPK oleh Dinas Pendidikan mendistribusikan kepada Guru calon Kepala Sekolah, (h) Guru mengisi 
Instrumen AKPK dan dikumpulkan pada waktu seleksi Akademik (Wasitohadi, 2016).

Berdasarkan gambar 2.1, menunjukan proses perekrutan calon kepala sekolah di Kabupaten Bima sesuai dengan hasil wawancara pra penelitian mengikuti langkahlangkah:(a) Dikpora membuat pengumuman dan sekaligus menyampaikan kepada pengawas sekolah, (b) pengawas dan UPTD meyampaikan kepada masing-masing kepala sekolah bahwa ada perekrutan kepala sekolah baru oleh Dikpora, (c) kepala sekolah menetapkan calon kepala sekolah yang akan direkomendasikan berdasarkan kepangkatan, dan jabatan tambahan di sekolahnya. Disamping itu Dikpora dapat menetapkan cakep secara vertikal baik penetapan langsung dengan pengawas maupun penetapan langsung dengan kepala sekolah atas instruksi langsung dari Bupati. Sehingga Dikpora memiliki kewenangan ganda dalam merekrut calon kepala sekolah, yaitu kewenangan umum, di mana calon kepala sekolah diusulkan berdasarkan prosedur yang berlaku dan kewenangan khusus merekrut calon kepala sekolah bekerjasama dengan Bupati (wawancara dengan informan 6 dan 7).

\subsection{Proses pengangkatan kepala sekolah}

Pengangkatan kepala sekolah baik di sekolah dasar maupun sekolah menengah sampai sekarang didasarkan pada penilaian selama seseorang menjabat menjadi guru. pada umumnya guru-guru yang menonjol disekolahnya dan mendapat penilaian yang baik dari pihak atasan mempunyai harapan untuk diangkat menjadi kepala sekolah. Prosedur semacam ini mengandung kelemahan yang cukup serius. Keberhasilan sebagai guru tidak bisa begitu saja dijadikan dasar untuk menjadi kepala sekolah. Harus digunakan kriteria lain untuk pengangkatan seorang kepala sekolah (Ritonga \& Lestar, 2012).

\subsection{Konsep Implementasi Kebijakan}

Implementasi kebijakan dapat dipandang sebagai proses melaksanakan keputusan kebijakan yang biasanya berbentuk Undang-undang, peraturan Pemerintah dan Keputusan peradilan. Penelitian ini akan melihat dari sisi apa yang terjadi, yaitu ingin menganalisis bagaimana proses implementasi
Permendiknas No. 28 tahun 2010 tentang Penugasan guru sebagai kepala sekolah pada Sekolah Menengah Pertama di Kabupaten Bima Nusa Tenggara Barat.

Model implementasi kebijakan yang bisa dipakai untuk mengukur keberhasilan suatu implementasi kebijakan, yaitu: Model Implementasi Kebijakan Publik Menurut Rondinelli \& Cheema, 1983.

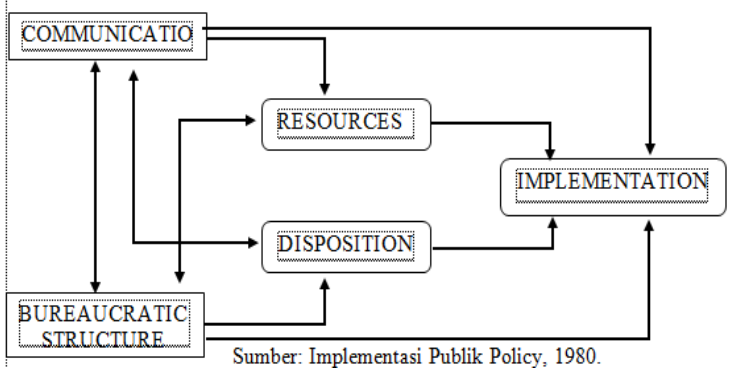

Diagram di atas akan diuraikan faktorfaktor yang menghambat keberhasilan implementasi Permendiknas No.28 Tahun 2010 di Kabupaten Bima Nusa Tenggara Barat. Yang akan diidentifikasi mulai dari : Sumber Daya. Sumber daya merupakan variabel penting dalam implementasi Permendiknas No.28/2010 karena merupakan kekuatan yang mendukung pencapaian tujuan Peraturan Menteri tersebut. Sebaliknya sikap pelaksana yang menyeleweng terhadap aturan cenderung bekerja di bawah intimidasi kepentingan pribadi dan kelompok. Hal ini akan menghambat proses implementasi.

\section{METODE PENELITIAN}

1. Jenis Penelitian

Penelitian ini menggunakan pendekatan kualitatif dengan jenis penelitian deskriptif. Penelitian ini mendeskripsikan informasi dan data proses penugasan guru sebagai kepala sekolah pada Sekolah Menengah Pertama di Kabupaten Bima Nusa Tenggara Barat.

2. Lokasi Penelitian

Penelitian ini dilakukan pada instansi DIKPORA dan BKD serta pada Sekolah Menengah Pertama. Alasan dilakukan penelitian pada DIKPORA dan BKD Kabupaten Bima karena merupakan salah satu instansi yang ditugaskan untuk melakukan kegiatan penerimaan calon kepala sekolah, mulai dari tahap perekrutan, seleksi, dan 
sampai pada tahap penetapan. Data dan Sumber data

Data primer dan data sekunder Untuk data primer diperoleh secara langsung dari instansi terkait yaitu Dikpora, BKD dan Kepala Sekolah yang menjabat pada tahun 2015. Sedangkan data sekunder diperoleh dari hasil dokumentasi.

3. Subjek Penelitian

Subjek untuk memperoleh data adalah; Kasi KPMP, Kepala Mutasi dan Rotasi, Staf BKD bagian Mutasi dan Rotasi, Staf BKD bagian Diklat dan guru. Yang berturut-turut disebut informan 6, informan 7, informan 8, informan 9, dan informan 10. Karena penilitian difokuskan pada tahun 2015, maka yang dijadikan subjek adalah kepala sekolah yang diangkat pada tahun 2015, yang berjumlah 13 kepala sekolah yang baru dilantik di Kabupaten Bima Nusa Tenggara Barat, kemudian dipilih 5 orang kepala sekolah, karena dianggap telah memberikan informasi sesuai dengan masalah yang diteliti. Yang terdiri dari; Kepala SMPN 10 Soromandi, Kepala SMPN 1 Donggo, Kepala SMPN 9 Soromandi, Kepala SMPN 4 Donggo dan Kepala SMPN 3 Sanggar. Yang berturut-turut disebut informan 1, informan 2, informan 3, informan 4 dan informan 5.

4. Instrumen Penelitian

Instrumen penelitian adalah peneliti sendiri. Peneliti menetapkan fokus penelitian, memilih informan, malakukan pengumpulan data, menilai kualitas data, menganalisis data, menafsirkan data dan membuat laporan hasil penelitian (Sugiyono, 2008).

5. Teknik Pengumpulan Data

Teknik yang digunakan untuk memperoleh data yaitu:

\subsection{Observasi}

Observasi dilakukan mendapatkan gambaran objektif mengenai proses pengangkatan Kepala Sekolah Menengah Peratama. Yang berisi data kegiatan pegawai pada instansi DIKPORA dan BKD yang berkaitan dengan perekrutan calon kepala sekolah.

\subsection{Wawancara}

Wawancara merupakan proses tanya jawab yang dilakukan terhadap informan. Menurut Sugiyono (2013) wawancara merupakan pertemuan dua orang untuk bertukar informasi dan ide malalui tanya jawab sehingga dapat dikonstruksikan makna dalam satu topik tertentu. Berdasarkan alasan di atas wawancara dilakukan terhadap Kasi KPMP DIKMEN pada dinas DIKPORA, bagian Mutasi di kantor BKD dan Kepala Sekolah di Kabupaten Bima Nusa Tenggara Barat untuk memberikan informasi berupa perekrutan calon kepala sekolah dan pengangkatan.

Gabungan antara teknik wawancara dan observasi dilakukan untuk mengetahui informasi tentang implementasi, faktor pendukung/penghambat, dan upaya mengatasi hambatan perekrutan dan pengangkatan calon kepala sekolah.

\subsection{Dokumentasi}

Dokumentasi untuk mengumpulkan data baik dalam bentuk tulisan, gambar mengenai lokasi penelitian, dokumen yang dibutuhkan antara lain data kepala Sekolah Menengah Pertama sebagai calon kepala sekolah, keputusan kepala DIKPORA dan BKD.

6. Teknik Analisis Data

Teknik analisis data menggunakan model Miles dan Huberman (2009) yaitu :

1) Pengumpulan data. Data yang diperoleh melalui metode observasi, wawancara dan dokumentasi,.

2) Reduksi data. Proses pemilihan, pemusatan perhatian, penyederhanaan, serta meringkas data yang sudah terkumpul dan ditransferkan dalam bentuk transkrip yang diberi kode sesuai kelompok rumusan masalah.

3) Penyajian data. Menyajikan dalam bentuk laporan, data yang disajikan dalam bentuk kalimat verbal, gambar, diagram dan dipertegas dengan hasil wawancara yang berkaitan dengan implementasi Permediknas no.28 tahun 2010 tentang penugasan guru sebagai kepala Sekolah.

4) Penarikan kesimpulan. Memberikan kesimpulan tentang dari hasil pengamatan, peramalan, penafsiran dan evaluasi yang disesuaikan dengan data yang diperoleh melalui metode pengumpulan data dengan tujuan 
memberikan penjelasan berdasarkan masalah yang dirumuskan.

Teknik analisis data tersebut digambarkan dalam bentuk alur berikut:

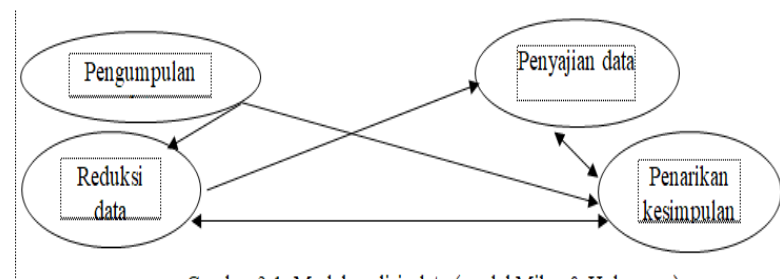

Gambar 3.1. Model analisis data (model Miles \& Huberman)

\section{Pengecekan Keabsahan Data}

Uji keabsahan data dapat dilakukan dengan cara triangulasi yaitu, dengan triangulasi sumber, dan triangulasi teknik pengumpulan data. Teknik triangulasi berdasarkan pendapatnya Wiliam Wiersma, 1986 dalam sugiyono, yaitu:

1) Triangulasi dengan tiga sumber data

Triangulasi sumber menguji kredibilitas data dengan mengecek data yang diperoleh melalui beberapa sumber. Pengumpulan dan pengujian data yang diperoleh dilakukan terhadap Dikpora, BKD dan Kepala Sekolah. Selanjutnya dideskripsikan, dikategorikan melihat kesamaan, perbedaan dari tiga sumber data tersebut.

2) Triangulasi teknik

Triangulasi teknik menguji kredibilitas data dilakukan dengan cara mengecek data kepada sumber yang sama dengan teknik yang berbeda. Misalnya data diperoleh dengan wawancara, lalu dicek dengan observasi, dan dokumen. Bila dengan tiga teknik pengujian kredibilitas data tersebut, menghasilkan data yang berbeda-beda, maka dapat melakukan diskusi lebih lanjut kepada sumber data yang bersangkutan atau yang lainya, untuk memastikan data mana yang dianggap benar.

\section{HASIL PENELITIAN}

1. Mekanisme Perekrutan Calon Kepala Sekolah pada Sekolah Menengah Pertama di Kabupaten Bima Nusa Tenggara Barat

\subsection{Tahap Pengumuman oleh DIKPORA.}

Dinas pendidikan Kabupaten Bima Nusa Tenggara Barat meyampaikan informasi melalui UPTD dan pengawas pada masingmasing kecamatan selanjutnya disampaikan ke setiap sekolah, kemudian kepala sekolah menyiapkan dan merekomendasikan guruguru yang memenuhi persyaratan untuk mengikuti tes calon kepala sekolah, mulai dari tingkat Sekolah Dasar, Sekolah Menengah Pertama sampai dengan Sekolah Menengah Atas dengan jumlah sekolah keseluruhan sebanyak 547 sekolah. Dengan pembagian berdasarkan jenjang yaitu; SD sebanyak 413 sekolah (lihat dilampiran), SMP sebanyak 91 sekolah dan SMA sebanyak 43 sekolah (lihat dilampiran).

Berdasarkan hasil observasi pada tanggal 29 agustus 2016 di Dikpora Kabupaten Bima Nusa Tenggara Barat terdapat dua orang pengawas dari Kecamatan Wera yang menyerahkan berkas lamaran kepala sekolah ke Kasi KPMP Dikmen Dikpora, hal ini dapat dikatakan bahwa prosedur perekrutan cakep harus melalui pengawas sekolah. Sebagaimana yang disampaikan informan 6.

"secara teknis kami bisa langsung menentukan nama guru-guru untuk diusulkan menjadi calon kepala sekolah berdasarkan data hasil laporan pengawas dari masing-masing sekolah guna mempercepat proses perekrutan, namun secara operasional untuk memperoleh calon kepala sekolah yang layak serta sesuai dengan kebutuhan sekolah, kami memerlukan bantuan dari pihak-pihak yang terlibat langsung dilingkungan sekolah dan yang mengetahui secara objektif keadaan sekolah tersebut".

1.2.Tahap Pengusulan oleh Kepala Sekolah

Kepala sekolah dan pengawas membentuk jalur koodinasi guna menyiapkan calon kepala sekolah berupa pemberian rekomendasi oleh kepala sekolah yang disetujui oleh pengawas. Dari hasil wawancara terhadap masing-masing informan, diperoleh hasil yang berbeda-beda. Hal ini sebagaimana yang disampaikan informan 2.

"yang mengusulkan saya adalah kepala Sekolah SMPN 2 Bolo yang bekerjasama dengan pengawas sekolah, karena pada saat itu saya menjabat sebagai Wakasek. 
Sedangkan menurut informan 3.

"saya tidak mengajukan lamaran dan tidak diusulkan oleh kepala sekolah, karena sudah ditetapkan oleh Dikpora dan Bupati".

Sedangkan menurut informan 5.

"secara tertulis tidak ada rekomendasi yang diberikan oleh kepala sekolah kepada saya, tapi sacara lisan kepala sekolah dan pengawas memberikan ijin kepada saya untuk mengajukan diri ke Dikpora untuk mengikuti cakep, karena menurut mereka saya pernah merintis sekolah di Kecamatan Sanggar yaitu SMPN 3 sanggar maka akan diprioritaskan untuk dipromisikan menjadi kepala sekolah".

Berdasarkan hasil wawancara di atas menunjukan adanya keberagaman jawaban yang disampaikan masing-masing informan, walaupun dengan jenis pertanyaan yang sama. 1.3.Tahap Seleksi Administrasi dan Akademik oleh DIKPORA

Seleksi administrasi yaitu pemeriksaan kelengkapan dokumen oleh panitia bagian penerimaan calon kepala sekolah pada Dikpora Kabupaten Bima, bagi calon kepala sekolah setelah melengkapi persyaratan umum dan khusus. Sebagaimana yang disampaikan informan 6 .

"bagi guru-guru yang telah dinyatakan lulus seleksi administrasi selanjutnya akan kami ikut sertakan dalam proses tes calon kepala sekolah".

Seleksi akademik yaitu penilaian potensi kepemimpinan dan penguasaan awal kompetensi kepala sekolah yang mencakup pemahaman tentang tugas dan tanggung jawab. Seleksi akademik dilakukan dengan tes wawancara dan tes tulis. Sebagaimana yang disampaikan informan 1 .

"pada saat mengikuti tes calon kepala sekolah yang pernah kami lakukan yaitu tes wawancara dan tes tulis yang diadakan oleh LPMP Provinsi, Dikpora Kabupaten dan Dikpora Provinsi”.

\subsection{Tahap Pengusulan oleh DIKPORA}

Pengusulan kepala sekolah melalui dua jalur, yaitu jalur umum dan jalur khusus. Jalur umum yaitu calon kepala sekolah yang diusulkan berdasarkan pengusulan kepala sekolah dan pengawas. Sedangkan jalur khusus langsung ditetapkan oleh Dikpora dan Bupati berdasarkan kinerja yang pernah dilakukan. Misalnya pernah merintis sekolah dan dianggap cakap untuk menjadi kepala sekolah. Sebagaimana yang disampaikan informan 4.

"secara formalitas saya tidak mengikuti prosedur yang berlaku untuk mengajukan diri mengikuti calon kepala sekolah, hanya saja sebelumnya pernah mengajukan permohonan ke pemerintah Daerah agar membangun sebuah sekolah di Kecamatan Soromandi yang berstatus SATAP, pada saat itu juga saya langsung ditunjuk untuk menjadi koordinator pada sekolah tersebut".

2. Proses Pengangkatan Kepala Sekolah 2.1.Pelaksanaan Pengangkatan Kepala Sekolah

\subsubsection{Pengangkatan Kepala Sekolah Berdasarkan Permendiknas No.28 Tahun 2010}

Pengangkatan Kepala Sekolah melalui Permendiknas No.28 Tahun 2010 diawali dengan tahapan sebagai berikut :

2.1.2. Program Pendidikan dan Pelatihan

Bedasarkan prosedur yang diatur dalam Permendiknas no.28/2010 pasal 6 poin 1 menjelaskan bagi Guru yang telah lulus seleksi calon kepala sekolah sebagaimana dimaksud dalam Pasal 5 harus mengikuti program pendidikan dan pelatihan calon kepala sekolah di lembaga terakreditasi. Sebagaimana yang disampaikan informan 6

"bagi guru-guru yang lulus seleksi administrasi dan akademik akan diberi tugas untuk mengikuti diklat yang diselenggarakan pada kantor BKD Kabupaten Bima Nusa Tenggara Barat”.

BKD Kabupaten Bima melakukan hubungan kerjasama dengan lembaga LPPKS, LP4TK, Lembaga Penjamin Mutu Pendidikan (LPMP) baik yang berada di dalam maupun diluar Kabupaten Bima Nusa Tenggara Barat. Lembaga yang ditunjuk oleh menteri sebagai penyelenggara kegiatan pendidikan dan pelatihan calon kepala sekolah adalah 
lembaga-lembaga yang telah terakreditasi dan diakui keberadaanya sebagai lembaga pemberdayaan kepala sekolah. Sebagai mana yang diungkapakan informan 6 ;

"lembaga yang ditunjuk oleh menteri untuk menyelenggarakan pendidikan dan pelatihan calon kepala sekolah yang kami tahu yang telah bekerjasama dengan BKD adalah LP4TK Solo dan LPMP NTB sebagai narasumber dan statusnya telah terakreditasi”.

Sedangkan menurut informan 9 menyatakan "lembaga yang telah bekerjasama dengan kami dalam penyelenggaraan diklat calon kepala sekolah adalah lembaga pengembangan dan pemberdayaan kepala sekolah (LPPKS) dan Lembaga Penjamin Mutu Pendidikan.

Adapun meteri pembelajaran teoritik pada kegiatan pendidikan dan pelatihan calon kepala sekolah yaitu seperti yang tertera pada tabel berikut :

Tabel.4.2 Materi diklat Kompetensi Calon Kepala Sekolah

\begin{tabular}{|c|c|c|c|}
\hline No & Materi Kompetensi & No & $\begin{array}{c}\text { Materi Pengembangan Profesi dan } \\
\text { Mutuatan Subtantif }\end{array}$ \\
\hline 1 & Manajemen Kepemimpinana Pendidikan I & 1 & Jam Pimpinan/Pembinaan \\
\hline 2 & Manajemen Kepemimpinana Pendidikan II & 2 & Pola Pikir PNS \\
\hline 3 & Manajemen Pendidikan/Kebijakan PNS & 3 & Pengawasan \\
\hline 4 & Kompetensi Sosial & 4 & Perpajakan \\
\hline 5 & Kompetensi Kewirausahaan/Profesional & 5 & Manajemen Kepegawaian Negara \\
\hline 6 & Kepribadian & 6 & Komunikasi yang Efektif \\
\hline 7 & Standar Pendidikan Nasional & 7 & Penelitian Tindakan Kelas \\
\hline
\end{tabular}

Pembelajaran teoritik mencakup materi kompetensi sedangkan praktek pengalaman lapangan mencakup materi pengembangan profesi. Menurut informan 9 bahwa untuk pelaksanaan program pendidikan dan pelatihan calon kepala sekolah pelaksanaannya selama 45 hari, dengan rincian sebagai berikut;

"waktu yang digunakan untuk kegiatan tatap muka selama program diklat sesuai jadwal yang ditentukan adalah 15 hari".

"untuk waktu praktek pengalaman lapangan selama program diklat adalah 1 bulan". "untuk Kabupaten Bima Nusa Tenggara Barat pelaksanaan kegiatan pendidikan dan pelatihan dipusatkan di Hotel Laila Kota Bima".

2.1.3. Penilaian Akseptabilitas oleh Tim Pertimbangan

Akseptabilitas dalam kamus bahasa indonesia diartikan sebagai hal-hal dapat diterima, keterterimaan, atau kecocokan dan kepantasan. Jika dikaitkan dengan proses pengangkatan kepala sekolah maka akseptabilitas menekankan pada aspek cocok, pantas atau layakkah seorang guru untuk diusulkan mengikuti calon kepala sekolah atau diangkat menjadi Kepala Sekolah. Berdasarkan hasil wawancara yang dilakukan terhadap informan 6 menyatakan;

"tim pertimbangan kepala sekolah melakukan penilaian kinerja terhadap calon kepala sekolah".

Berdasarkan uraian hasil wawancara di atas menunjukan bahwa tim pertimbangan melakukan penilaian akseptabilitas sebelum dan sesudah calon kepala sekolah mengikuti diklat maka atas dasar penilaian tersebut pihak BKD bagian mutasi dan rotasi mengajukan nama-nama calon kepala sekolah yang layak untuk diangkat menjadi kepala sekolah kepada pemerintah daerah (Bupati).

2.1.4. Pengangkatan Kepala Sekolah oleh Tim Pertimbangan

Tim pertimbangan yang terdiri dari pengawas sekolah dan dewan pendidikan. Pengawas sekolah melakukan penilaian dan memberikan laporan hasil kinerja guru kepada Dikpora, sedangkan dewan pendidikan memberikan pertimbangan dari hasil penilaian kinerja yang dievaluasi oleh Dikpora ke pemerintah Daerah. Berdasarkan SK Bupati Nomor: 821/2/1503.007.2014 tanggal 06 Februari 2015 M/16 Rabiul Akhir $1436 \mathrm{H}$, maka kepala BKD atas nama Bupati Bima telah melantik sebanyak 13 orang kepala sekolah di Kabupaten Bima Nusa Tenggara Barat secara defenitif pada tahun 2015 (nama kepala sekolah terlampir). Hal ini sesuai hasil wawancara dengan informan 8 .

"untuk pengangkatan Kepala Sekolah tidak dilakukan secara serentak tapi ditempatkan dan diangkat berdasarkan kebutuhan penyediaan calon kepala 
sekolah, misalnya ada kepala sekolah yang mencapai masa periodesasi untuk 1 kali masa jabatan maka akan diganti, kemudian bagi Kepala Sekolah yang pensiun juga akan diganti jabatanya. Sebagai contoh dari jumlah calon kepala sekolah yang lulus tes adalah 88 orang, maka akan dirinci dari 88 orang ada sebagian yang akan diangkat langsung menjadi Kepala Sekolah dan ada sebagian yang tidak langsung diangkat melainkan harus menunggu masa pensiunan dan berakhir masa jabatan Kepala Sekolah yang lama".

2.1.5. Pengangkatan Kepala Sekolah Berdasarkan PP No.100 Tahun 2000

Proses pengangkatan kepala Sekolah Menengah Pertama di Kabupaten Bima Nusa Tenggara Barat di berbagai sekolah yaitu di SMPN 1 Donggo, SMPN 10 Soromandi, SMPN 9 Soromandi, SMPN 3 Sanggar hampir semua sama yaitu pengangkatan kepala sekolah setelah dinyatakan lulus Calon kepala sekolah sesuai dengan amanat Permendiknas no.28/2010 kecuali pada SMPN 4 Donggon dan SMPN 3 Tambora yang pengangkatan Kepala Sekolah Berdasarkan Kebijakan langsung dari Bupati dengan memberikan nota tugas sementara No: 006/2267/01.1/A/2014 oleh Kepala Dikpora Kabupaten Bima Nusa Tenggara Barat. Hal ini sebagaimana yang disampaikan informan 4.

"karena saya pernah mengusulkan ke Bupati agar didirikan sekolah SATAP di Kecamatan Donggo dan sekarang menjadi SMPN 8 Soromandi, dengan dasar itulah saya langsung di Pltkan pada Sekolah SMPN 4 Donggo dan menjadi koordinator pada SMPN 8 Soromandi selain itu juga mengingat saya juga memiliki jasa terhadap Bupati yang menjabat saat itu".

Berdasarkan hasil wawancara yang dilakukan terhadap informan 4 di atas jika dihubungkan dengan alasan terhadap implementasi PP. No 100/2000 maka akan diketahui adanya hak prerogatif pemerintah daerah dalam hal ini bupati. Hal ini sabagaimana yang disampaikan informan 7 . "merupakan sebuah keniscayaan bagi pemerintah daerah dalam hal ini Bupati untuk memanfaatkan kekuasaanya, karena memang segala keputusan yang kami ambil harus diketahui dan disetujui oleh Bupati, kami hanya bekerja berdasarkan surat perintah dari Bupati, berkaitan dengan pengangkatan kepala sekolah sebagai Plt merupakan hak prerogatifnya. Hak prerogatif itu hanya berlaku untuk hal-hal yang berkaitan dengan jabatan-jabatan fungsional saja".

2.1.6. Jumlah Kepala Sekolah yang diangkat sejak diberlakukan permendiknas No.28 Tahun 2010.

Hal ini perlu dilakukan agar ada studi komparasi terhadap pergantian jabatan kepala sekolah pada setiap masa periodesasi, karena tidak menutup kemungkinan pengaruh peralihan jabatan kepala daerah berdampak pada regulasi rotasi dan mutasi kepala sekolah. Berikut ini akan disajikan data kepala sekolah yang dirangkum dari tahun 2013-2015 (terlampir).

2.1.7. Jumlah kepala sekolah yang diangkat berdasarkan PP No.100/2000 Tahun 2015.

Berdasarkan data dari BKD Kabupaten Bima Nusa Tenggara Barat bahwa kepala sekolah yang diangkat berdasarkan PP No.100/2000 sebagai berikut:

Tabel.4.1 Data Guru yang diangkat menjadi Kepala Sekolah yang berstatus sebagai Plt tahun 2015

\begin{tabular}{|c|l|c|c|c|l|}
\hline No & \multicolumn{1}{|c|}{ NamaNip } & $\begin{array}{c}\text { Pangkat } \\
\text { /Gol }\end{array}$ & Tugas Lama & Tugas Barı & Kecamatan \\
\hline \multirow{2}{*}{1} & $\begin{array}{l}\text { Muhammad Lubis, S. Ag } \\
197212312008011124\end{array}$ & $\begin{array}{c}\text { Penata, } \\
\text { III/c }\end{array}$ & $\begin{array}{c}\text { Plt. Kepala } \\
\text { SMPN 4 } \\
\text { Dongo }\end{array}$ & $\begin{array}{c}\text { Kepala } \\
\text { SMPN 4 } \\
\text { Dongg0 }\end{array}$ & Donggo \\
\hline \multirow{2}{*}{2} & Kusnadi, S.Pd & Penata, & $\begin{array}{c}\text { Plt. Kepala } \\
\text { SMPN 3 }\end{array}$ & $\begin{array}{c}\text { Kepala } \\
\text { SMPN 3 }\end{array}$ & Tambora \\
& 197308072008011013 & III/c & Tambora & Tambora & \\
\hline
\end{tabular}

2.1.7.1.Jumlah Kepala Sekolah yang diangkat Tahun 2015

Berdasarkan SK Bupati Nomor: 821/2/1503.007.2014 tanggal 06 Februari 2015 M/16 Rabiul Akhir 1436 H, maka kepala BKD atas nama Bupati Bima telah melantik sebanyak 13 orang kepala sekolah di Kabupaten Bima Nusa Tenggara Barat secara defenitif pada tahun 2015 (terlampir). 
3. Faktor Pendukung dan Penghambat implementasi Permendiknas No. 28 Tahun 2010 di Kabupaten Bima Nusa Tenggara Barat.

\subsubsection{Faktor Penghambat}

\subsubsection{Faktor Internal}

Faktor penghambat yaitu tidak adanya upaya sosialisasi DIKPORA Provinsi terkait pelaksanaan pengangkatan kepala sekolah berdasarkan instruksi permendiknas no.28/2010 sehingga pihak DIKPORA Kabupaten Bima Nusa Tenggara Barat mengalami kesulitan dalam mengiterpretasikan isi permendiknas tersebut, sebagaimana yang dikatakan informan 6 .

"Dikpora Kabupaten Bima Nusa Tenggara Barat selama 5 tahun masih menggunakan Permendiknas No.13 Tahun 2007 sabagai acuan dalam merekrut Kepala Sekolah, baru pada tahun 2012 kami mulai menerapkan Permendiknas No.28 Tahun 2010 untuk merekrut Calon kepala sekolah, hal ini disebabkan karena kami belum memahami secara keseluruhan isi dari Permendiknas tersebut, sehingga kami membutuhkan waktu untuk mempelajarinya".

Selain itu, faktor pembiayaan yang dianggarkan oleh pemerintah Daerah melalui APBD untuk pengadaan calon kepala sekolah belum mencukupi baik untuk kegiatan perekrutan maupun untuk kegiatan diklat calon kepala sekolah. Hal ini sebagaimana yang dikatakan oleh informan 6 .

"Kedala yang kami hadapi dalam penyelenggaraan perekrutan dan diklat calon kepala sekolah berkaitan dengan biaya, APBD Kabupaten Bima Nusa Tenggara Barat belum cukup sesuai kuata peserta".

"untuk itu upaya yang akan kami lakukan untuk mengatasinya dengan langkah mengajukan tambahan anggaran melalui APBD pada tahun 2016".

\subsubsection{Faktor Eksternal}

Peran pemerintah daerah dalam penyelenggaraan pendidikan menjadi bumerang bagi instansi pendidikan karena pengaruh hegomoni kekuasaan menjadi alasan untuk mengatur segala sektor instansi yang ada di daerah berdasarkan selera dan otoritas pribadi termasuk sektor pendidikan. Hal ini akan memicu Adanya oktum-oktum yang tidak bertanggung jawab yang mengatas namakan tim pertimbangan, namun sebenaranya mereka dalah tim sukses Bupati untuk mengitimidasi calon kepala sekolah dengan cara menawarkan jasa untuk meloloskan menjadi kepala sekolah dengan ketentuan harus menyerahkan materi (uang) dalam jumlah yang cukup besar. Sebagaimana yang disampaikan informan 7 .

"laporan yang telah saya terima kebanyakan oktum tersebut berasal dari LSM, teman-teman wartawan yang sedikit nakal yang memanfaatkan momentum pilkada".

Selain itu, karena ketersedian SDM yang belum memadai baik kualitas maupun kuantitas di beberapa sekolah tertentu, pihak BKD bekerjasama dengan PPK dalam hal ini Bupati mengangkat kepala sekolah dengan prosedur menunjuk langsung guru-guru yang dianggap cakap untuk memimpin sekolahsekolah yang berada di daerah kategori terpencil.

Pemberlakuan PP no.100/2000 tentang pengangkatan pejabat struktural tidak menutup kemungkinan bisa diangkat menjadi Kepala Sekolah tanpa harus mengikuti tes calon kepala sekolah walaupun status Plt karena dominasi pemerintah daerah menetapkan kebijakan melalui PP tersebut sangat besar dengan berbagai pertimbangan yang menjadi dasar dalam mengambil keputusan.

3.1.2. Faktor Pendukung

3.1.2.1.Faktor Internal

Peran pemerintah daerah tidak hanya berdampak buruk pada institusi pendidikan melainkan sebagai bentuk kepedulian terhadap pendidikan dengan pihak-pihak (steakholder) lain dalam membangun hubungan kerjasama guna menata, mengembangkan dan memajukan pendidikan yang bermutu. Di Kabupaten Bima Nusa Tenggara Barat telah banyak sekolah yang dibangun disetiap kecamatan hampir lebih 
dari 5 Sekolah Menengah Pertama yang berstatus SATAP dan sekolah-sekolah tersebut dipimpin oleh kepala sekolah yang berstatus Plt, namun tidak membutuhkan waktu lama sejak tahun 2010 semua sekolah yang berstatus SATAP oleh Bupati Kabupaten Bima Nusa Tenggara Barat merubah statusnya menjadi sekolah Negeri dan kepala sekolah diangkat secara definitif oleh Bupati.

Salain itu, kualifikasi guru-guru yang mengikuti calon kepala sekolah yang berijasah S2 setiap tahun mengalami penambahan, hal ini menunjukan kompetensi seorang kepala sekolah sangat menentukan oleh kualitas keilmuan sehingga mutu pendidikan akan lebih baik. Sebagaimana yang disampaikan informan 6 .

"untuk sekolah di Kabupaten Bima Nusa Tenggara Barat yang mengusulkan guru-guru yang berkualifikasi S2 untuk mengikuti calon kepala sekolah; untuk sekolah menengah atas terdiri dari; SMA Lambitu, SMA 2 Langgudu, SMA 1 Bolo, SMA 1 Monta, SMA 2 Woha, SMA 1 Woha dan SMA 1 Donggo. Untuk Sekolah Menengah Pertama terdiri dari; SMPN 1 Madapangga, SMP 2 Bolo dan SMP 3 Madapangga. Untuk Sekolah Dasar terdiri dari; SD Kawinda Na'e dan SD 2 Tente".

\subsubsection{Faktor Eksternal}

BKD Kabupeten Bima membangun hubungan kerjasama dengan lembaga LPPKS, LP4TK, Lembaga Penjamin Mutu Pendidikan (LPMP) baik yang berada di Kab Bima maupun diluar Kab Bima. Sebagai mana yang diungkapakan informan 6;

"lembaga yang ditunjuk oleh menteri untuk menyelenggarakan pendidikan dan pelatihan calon kepala sekolah yang kami tahu yang telah bekerjasama dengan BKD adalah LP4TK Solo dan LPMP NTB sebagai nara sumber dan statusnya telah terakreditasi".

4.4 Upaya yang dilakukan mengatasi hambatan dalam implementasi Permendiknas No.28 Tahun 2010 di Kabupaten Bima Nusa Tenggara Barat.

\subsubsection{Faktor internal \\ Upaya untuk mengatasi hambatan} implementasi Permendiknas No.28 tahun 2010 pada Sekolah Menengah Pertama di Kabupaten Bima Nusa Tenggara Barat sesuai hasil wawancara dengan informan 6.

"sejauh ini dari Dikpora sendiri berupa menyesuiakan antara isi Permendiknas No.28 Tahun 2010 dengan Permendiknas No.13 Tahun 2007 dikarenakan kami belum memahami secara keseluruhan isi dari permendiknas yang baru, itu kami lakukan selama lima Tahun, salah satu isi dari permendiknas yang disesuaikan yang berkaitan dengan kelengkapan administrasi berupa persyaratan umum dan persyaratan khusus".

Hal senada sebagaimana yang disampaikan oleh informan 5 .

"saya pernah mengajukan lamaran calon kepala sekolah sejak tahun 2007, hanya berupa ijasah terakhir dan SK kenaikan pangkat/golongan, sampai sekarangpun masih diberlakukan hal yang sama bagi calon kepala sekolah baru".

Berdasarkan hasil wawancara di atas upaya yang dilakukan mengatasi hambatan kurangnya pemahaman Dikpora dalam penerapan Permendiknas No.28 Tahun 2010 adalah dengan memberikan keringanan kepada calon kepala sekolah dalam melengkapi berkas lamaran, yang terpenting adalah berkualifikasi ijasah S1 dan berpangkat/gol paling rendah III/c.

4.4.2 Faktor Eksternal

Upaya untuk mengatasi adanya keterlibatan tim sukses Bupati dalam mengitimidasi calon kepala sekolah untuk melakukan praktek pungli dalam proses pengangkatan, maka informan 7 menegaskan,

"kami tidak akan mempublikasikan kepihak manapun nama-nama calon kepala sekolah yang dilantik sebelum disetujui secara legalitas oleh Bupati,walaupun memiliki hak proregatif'. 


\section{PEMBAHASAN}

1. Mekanisme Perekrutan Calon Kepala Sekolah di Kabupaten Bima Nusa Tenggara Barat

Perekrutan calon Kepala Sekolah Menengah Pertama di Kabupaten Bima Nusa Tenggara Barat dilakukan melalui beberapa tahapan yaitu; Tahap pengumuman, merupakan prosedur penyebaran informasi mengenai penerimaan dan perekrutan calon kepala sekolah baru kesemua institusi pendidikan mulai dari Pendidikan Dasar, Pendidikan Menengah Pertama, dan Pendidikan Menengah Atas malalui pengawas sekolah, dan UPTD disetiap Kecamatan di Kabupaten Bima Nusa Tenggara Barat. Tahap ini perlu dilakukan agar guru-guru mendapatkan kesempatan yang sama untuk mendaftarkan diri mengikuti tes calon kepala sekolah.

Tahap pengusulan oleh kepala sekolah, pada tahap ini kepala sekolah mengusulkan nama-nama guru yang diurutkan berdasarkan tugas tambahan disekolah dan berdasarkan kepangkatan/golongan, seperti tugas tambahan sebagai Wakasek, Waka kurikulum, Waka Kesiswaan, Waka Humas dan Waka SARPRAS. Tahap seleksi administrasi dan akademik, pada tahap ini panitia perekrutan calon kepala sekolah melakukan seleksi mencakup kelengkapan persyaratan umum dan persyaratan khusus. Persyaratan khusus mencakup status sebagai guru pada sekolah yang akan diberi tugas tambahan sebagai kepala sekolah dan telah memperoleh sertifikat kepala sekolah. Sedangkan persyaratan umum mencakup kualifikasi akademik, surat kesehatan jasmani dan rohani dari dokter, keterangan tidak pernah dikenakan hukuman disiplin, sertifikat pendidik, sertifikat pengalaman mengajar, kualifikasi golongan, usia maksimal mengikuti calon kepala sekolah. Kemudian setelah calon kepala sekolah memenuhi persyaratan umum dan khusus selanjutnya akan diikut sertakan untuk mengikuti tes calon kepala sekolah.

Tahap pengusulan oleh Dikpora, Pengusulan oleh Dikpora Kabupaten Bima Nusa Tenggara Barat melalui dua jalur, yaitu jalur umum dan jalur khusus. Jalur umum diusulkan berdasarkan pengusulan kepala sekolah dan pengawas. Sedangkan jalur khusus langsung ditetapkan oleh Dikpora dan Bupati berdasarkan kinerja yang pernah dilakukan. Misalnya pernah merintis sekolah dan dianggap cakap untuk menjadi kepala sekolah. Hal ini sebagaimana yang disampaikan oleh informan 4. Bagi calon kepala sekolah yang diusulkan melalui jalur umum akan diikut sertakan mengikuti diklat calon kepala sekolah. Sedangkan calon kepala sekolah yang diusulkan melalui jalur khusus disesuaikan dengan kebijakan Bupati.

Temuan hasil penelitian di atas didukung oleh hasil penelitian yang dilakukan Irianto (2014) dalam penelitiannya yang berjudul "Evaluasi Model Rekrutmen Kepala Sekolah di Surakarta”. Berdasarkan hasil penelitian Irianto, dilakukan berdasarkan tiga prinsip meliputi; (1) rutin pada awal tahun berdasarkan hasil analisis dengan penetapan formasi jabatan kepala sekolah; (2) dilakukan secara proaktif dalam rangka mendapatkan guru yang paling menjanjikan untuk menjadi kepala sekolah; (3) dilakukan secara terbuka melalui surat kabar lokal dalam rangka memberikan kesempatan yang seluas-luasnya kepada guru yang memenuhi kualifikasi.

Perekrutan calon kepala sekolah merupakan upaya kolaboratif yang melibatkan banyak lembaga, dengan tujuan agar menghasilkan kepala sekolah yang kompeten untuk memajukan lembaga sekolah. maka oleh Lembaga Pengembangan dan Pemberdayaan Kepala Sekolah merancang model rekrutman calon kepala sekolah.

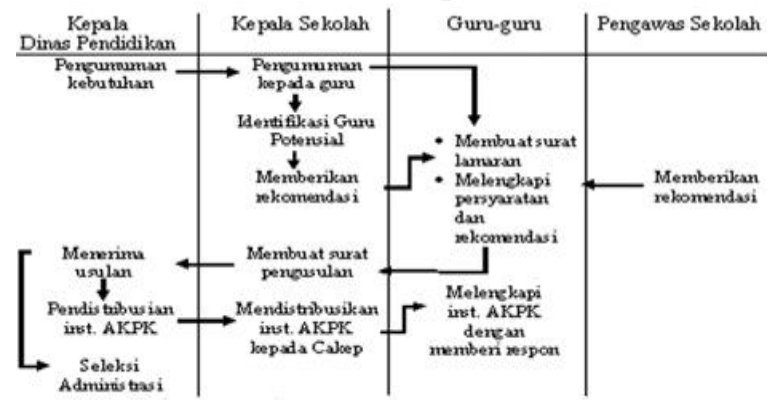

Garmbar.5.1 Alur Proses Pengusulan Calon Kepala Se kolah (sumber. LPFKS, 2013)

Gambar di atas menunjukan perlu adanya hubungan kerjasama yang berkesinambungan bersifat sinergi antara lembaga penyelenggara yaitu Dikpora dengan lembaga pengusul calon kepala sekolah yaitu kepala sekolah, guru dan pengawas sekolah. 
Secara prosedural LPPKS menyusun sistem perekrutan berdasar pada permendiknas no. 28 tahun 2010 agar dalam pelaksanaan oleh masing-masing lembaga terukur dan terstruktur sehingga tidak ada jalur kerja yang saling mendahului.

Berdasarkan hasil penelitian yang dilakukan jika dikaitkan dengan alur proses perekrutan yang dirancang oleh LPPKS ada beberapa aspek yang tidak sesuai dalam perekrutan calon kepala sekolah yang dilakukan oleh lembaga penyelenggara dan lembaga pengusul di Kabupaten Bima Nusa Tenggara Barat. Aspek pertama, berkaitan dengan pengumuman, Dikpora Kabupaten Bima Nusa Tenggara Barat menyampaikan informasi tentang perekrutan calon kepala sekolah masih bersifat personal tidak diumumkan secara publik. Secara teknik perekrutan calon kepala sekolah dapat ditentukan oleh Dikpora tanpa menunggu usalan dari kepala sekolah berdasarkan hasil laporan dari pengawas sekolah dengan indikasi bahwa pengawas telah melakukan penilaian kinerja selama menjadi guru. Aspek kedua, pengusulan oleh kepala sekolah, Selama ini penilaian kinerja yang dilakukan oleh pengawas sekolah terhadap guru calon kepala sekolah masih cenderung mengutamakan prestasi non akademik dengan mengesampingkan prestasi akademik. Prestasi non akademik yang dimaksud misalnya seorang guru pernah merintis sebuah sekolah, maka oleh pengawas sekolah dan kepala sekolah berasumsi bahwa dia layak untuk diberikan apreseasi dengan mengusulkannya untuk menjadi calon kepala sekolah. Sehingga akomodasi calon kepala sekolah kurang selektif. Aspek ketiga, pengusulan oleh Dikpora, berdasarkan pernyataan informan 3, pengusulan calon kepala sekolah langsung ditetapkan oleh Dikpora dan Bupati. Hal ini menunjukan bahwa penetapan calon kepala sekolah yang ditetapkan oleh Dikpora merupakan instruksi langsung dari Bupati.

Hasil analisis di atas didukung oleh hasil analisis yang disampaikan Haryadi (2015) dalam tulisannya "memperbaiki proses rekrutmen kepala sekolah" yang menyatakan proses reformasi membawa posisi kepala sekolah menjadi terdegradasi karena faktor politik. Mengapa disebutkan begitu karena otonomi daerah menyebabkan posisi kepala daerah memiliki wewenang luar biasa untuk menentukan orang-orang pilihannya untuk duduk dijabatan tertentu bahkan sampai dengan posisi kepala sekolah. Jabatan kepala sekolah diberikan sebagai bentuk balas budi mereka yang telah menjadi tim sukses calon kepala daerah.

Banyak kejadian di daerah muncul kepala sekolah baru dengan golongan baru saja naik dari III/b ke III/c langsung jadi kepala sekolah tanpa pernah jadi pembantu kepala sekolah. Hal ini seharusnya bisa direvisi dalam permendiknas 28. Seorang guru biasa tanpa pengalaman apapun menjadi kepala sekolah hanya karena faktor kedekatan politik dengan kepala daerah menjadikan sekolah seperti kelinci percobaan (kompasiana.com).

1.1.Pengangkatan Kepala Sekolah di

Kabupaten Bima Nusa Tenggara Barat.

Berdasarkan hasil temuan yang diuraikan pada hasil penelitian menunjukan bahwa proses pengangkatan kepala sekolah di Kabupaten Bima Nusa Tenggara Barat mengacu pada Permendiknas No.28/2010 dan Peraturan Pemerintah No.100/2000.

\subsubsection{Pengangkatan Kepala Sekolah Berdasarkan Permendiknas No.28 Tahun 2010}

Sebelum diterbitkan Permendiknas no. 28 tahun 2010 telah diterbitkan Permendiknas no.13 tahun 2007, sejak diterbitkanya Permendiknas No. 13 tahun 2007 tentang standar kepala sekolah hingga akhir tahun 2009 , belum ada instrumen yang digunakan untuk menyeleksi calon kepala sekolah ataupun mengukur kadar kompetensi kepala sekolah. Setiap daerah (Kabupaten/Kota) mempunyai kebijakan dan kriteria tersendiri untuk mengangkat, memutasikan, ataupun memberhentikan kepala sekolah. Kadangkadang kriteria umum dan persyaratan khusus yang diberlakukan secara nasional tidak dijadikan acuan dalam pengangkatan kepala sekolah. Kemendiknas belum memiliki instrumen baku untuk mengukur penguasaan kompetensi kepala sekolah, sehingga diketahui adanya kepala sekolah yang kompeten dan kepala sekolah yang kurang 
kompeten. Padahal, hasil pemetaan kompetensi kepala sekolah dapat dijadikan sebagai bahan pertimbangan untuk peningkatan kompetensi dan kinerja kepala sekolah.

Penyelenggaraan pemerintah pada otonomi daerah turut memberikan "warna" dalam seleksi, pengangkatan, penugasan, dan pemberhentian kepala sekolah, di mana unsur politis dan KKN lebih berperan dibandingkan dengan penilaian prestasi, sistem karir dan profesionalisme. Kondisi ini sangat bertentangan dengan upaya peningkatan mutu pendidikan (Manap, Pudji Hartuti, Puspa Djuwita, Komarudin, Muzanip Alperi, 2010). Permendiknas No.13 Tahun 2007 hanya mengatur standar kualifikasi dan kompetensi kepala sekolah, tanpa mengatur prosedur atau tata cara pengangkatan kepala sekola. Menyebabkan pengangkatan kepala sekolah yang dilakukan di Kabupaten Bima Nusa Tenggara Barat berdasarkan amanah Permendiknas no.13 tahun 2007 tersebut masih beragam, sabagaimana yang disampaikan oleh informan 1, pengusulan dan pengangkatan kepala sekolah pada tahun 2007 masih mengacu pada tugas guru dan kepangkatan. Tugas guru dilihat berdasarkan tugas tambahan sebagai Wakil kepala sekolah atau sebagai wakepala sekolah urusan. Sedangkan kepangkatan dilihat dari kategori golongan. Selain itu menurut informan 6 penerapan Permendiknas no.13 tahun 2007 dalam pengangkatan kepala sekolah di Kabupaten Bima Nusa Tenggara Barat sangat mudah untuk diterapkan karena prosedurnya tidak terlalu sulit, sehingga penerapan permendiknas tersebut berlangsung sampai tahun 2012.

Menata dan meroformasi kepemimpinan pendidikan di sekolah, sekaligus melengkapi peraturan sebelumnya yaitu Permendiknas No.13 Tahun 2007 yang terkait dengan kepala sekolahan, sekarang pemerintah melalui Menteri Pendidikan Nasional menghadirkan kembali regulasi Permendiknas No.28 Tahun 2010 tentang penugusan guru sebagai kepala sekolah. Calon kepala sekolah yang diangkat melalui permendiknas no.28 tahun 2010 idealnya harus dinyatakan lulus cakep, dan mengukuti program pendidikan dan pelatihan. Setelah dinyatakan lulus selanjutnya tim pertimbangan melakukan penilian akseptabilitas guna mengetahui kompetensi awal yang dimiliki oleh calon kepala sekolah tentang pelaksanaan tugas sebagai kepala sekolah, berdasarkan hasil penilaian akseptabilitas maka dapat diketahui calon kepala sekolah yang kompeten dan yang tidak kompeten, calon kepala sekolah yang kompeten akan dilantik secara definitif oleh Bupati, selanjutnya Bupati akan menerbitkan SK pengangkatan dan penempatan. Dengan keterlibatan tim pertimbangan yang di dalamnya terdapat unsur pengawas sekolah dan dewan pendidikan diharapkan pengangkatan kepala sekolah lebih mengedepankan asas transparansi dan objektif sehingga kompetensi kepala sekolah dapat menjamin peningkatan mutu pendidikan.

Proses pengangkatan kepala sekolah di Kabupaten Bima Nusa Tenggara Barat melalui Permendiknas no.28/2010 sampai saat ini masih didominasi oleh kebijakan pemerintah daerah dalam hal ini Bupati dalam hal penempatan dan pengangkatan kepala sekolah. Hal ini dapat dilihat melalui model pengangkatan yang terjadi di Kabupaten Bima Nusa Tenggara Barat, di mana bagi cakep yang dinyatakan lulus tes pada tahun 2007 akan diangkat pada tahun 2015. hal ini sebagaimana yang disampaikan oleh informan 2. Berdasarkan ketentuan yang berlaku sistem pergantian kepala sekolah harus berdasar pada masa periodesasi, maka kebijakan mengenai keterlambatan pengangkatan tidak dipermasalahkan, namun peristiwa selama ini menunjukan bahwa keterlambatan pengangkatan disebabkan karena calon kepala sekolah tidak berpartisipasi dalam mendukung Bupati dalam pemilihan kepala daerah, sehingga nama calon kepala sekolah yang dinyatakan lulus tes pada tahun 2007 tidak terkafer untuk segera dilantik. Sehingga memberi peluang bagi cakep yang baru yang ikut berpartisipasi dalam mendukung Bupati untuk diangkat dengan cepat walaupun statusnya baru lulus cakep pada tahun 2014, sebagaimana yang disampaikan oleh informan 3. 
Temuan hasil penelitian di atas didukung oleh penelitian yang dilakukan Jamali (2012) dengan penelitian yang berjudul "Evaluasi Of Recruitment Policy Implementation Head Of The State High School in Banda Aceh. Dalam hasil penelitiannya dikatakan tim pertimbangan pengangkatan kepala sekolah ditetapkan oleh walikota, dengan melibatkan unsur pengawas dan dewan pendidikan, BKPP, Pers dan tim pemantau independen, dengan adanya tim dari lintas keilmuan dan kelembagaan, diyakini akan dapat mengurangi kelemahan dan kecurangan dalam pengangkatan kepala sekolah.

\subsubsection{Pengangkatan Kepala Sekolah}

Berdasarkan PP No.100 Tahun 2000

Pemerintah menerbitkan PP no.100/2000 secara universal diberlakukan di seluruh wilayah di Indonesia, untuk mengangkat, memberhentikan pejabat yang diberi tugas sebagai Plt, pada semua instansi baik di pusat, Provinsi dan daerah Kabupaten/Kota. Pengangkatan kepala sekolah melalui PP No.100 Tahun 2000 tidak terlalu detail menetapkan syarat dan ketentuan bagi seseorang untuk diangkat menjadi pelaksana tugas, dari segi kualifikasi kepangkatan/golongan serendah-rendahnya menduduki 1 pangkat di bawah jenjang pangkat yang ditentukan, artinya jika tidak ada yang bergolongan IV, bisa diangkat yang bergolongan III yang berstatus PNS.

Peraturan Pemerintah No.100 Tahun 2000 pasal 1 menjelaskan syarat-syarat untuk dapat diangkat dalam jabatan struktural, antara lain serendah-rendahnya menduduki pangkat satu tingkat di bawah jenjang pangkat yang ditentukan. Atas dasar inilah pengangkatan kepala sekolah di Kabupaten Bima Nusa Tenggara Barat melalui PP No.100 Tahun 2000 terlihat berbeda dalam pelaksanaannya, banyak hal yang menuai kontroversi salah satu diantaranya, pengangkatan kepala sekolah sebagai Plt didominasi oleh guru-guru yang berpangkat/golongan III, sedangkan masih ada yang pangkat IV. Kepala sekolah yang diangkat menjadi Plt adalah guru yang pernah mengikuti tes Cakep namun belum lulus tes cakep tapi tetap diberi tugas menjadi kepala sekolah sebagai Plt. Melalui tugas sebagai Plt tidak menutup kemungkinan oleh Bupati akan diangkat secara definitif menjadi kepala sekolah tanpa melalui prosedur yang ditetapkan dalam Permendiknas No.28 Tahun 2010. Hal ini sebagaimana yang sampaikan oleh informan 4 , bagi guru yang memiliki kinerja baik selama memimpin sebuah lembaga pendidikan dengan status Plt, oleh pengawas dinilai layak untuk diajukan ke Bupati untuk ditindak lanjuti berdasarkan kewenangannya.

Berdasarkan Temuan di atas akan sesuai dengan yang disampaikan oleh informan 7 , merupakan sebuah keniscayaan peran pemerintah daerah dalam hal ini Bupati untuk memanfaatkan kekuasaanya, karena memang segala keputusan yang diambil harus diketahui dan disetujui oleh Bupati, tugas sebuah instansi hanya bekerja berdasarkan surat perintah dari Bupati, berkaitan dengan pengangkatan kepala sekolah sebagai Plt merupakan hak prerogatifnya. Hak prerogatif itu hanya berlaku untuk hal-hal yang berkaitan dengan jabatan-jabatan yang bersifat struktural saja.

1.2. Faktor Penghambat dan Pendukung

1.2.1. Faktor Penghambat

Berdasarkan hasil penelitian menunjukan salah satu faktor yang menghambat penerapan Permendiknas No.28 Tahun 2010 di Kabupaten Bima Nusa Tenggara Barat kurangnya partisipasi Dikpora provinsi dalam melakukan sosialisasi yang intensif terkait penerapan Permendiknas No.28 tahun 2010 ke masing-masing instansi Dikpora Kabupaten/Kota di Provinsi NTB termasuk di Kabupaten Bima Nusa Tenggara Barat, sehingga dalam perekrutan dan pengangkatan kepala sekolah beragam. Hal ini tidak terlepas dari kurangnya pemahaman panitia perekrutan calon kepala sekolah terhadap isi Permendiknas tersebut, sehingga tercatat Dikpora Kabupaten Bima Nusa Tenggara Barat mulai menerapkan Permendiknas No.28 Tahun 2010 sejak tahun 2012. Ini menunjukan Dikpora Kabupaten Bima Nusa Tenggara Barat dalam perekrutan dan pengangkatan kepala sekolah selama lima tahun terakhir masih mengacu pada Permendiknas No.13 Tahun 2007. 
Dampak Otonomi Daerah membuka ruang yang selus-luasnya kepada pemangku kebijakan tertinggi di daerah untuk mengambil andil dalam merekrut, mengangkat kepala sekolah baik untuk jabatan struktural maupun fungsional. Keterlibatan pemerintah daerah dalam penyelenggaraan pendidikan menjadi bumerang bagi institusi pendidikan karena keberadaan PNS ditingkat sekolah selalu digiring untuk ikut terlibat pada setiap ajang pemilukada. Hal ini akan menghadirkan kepala sekolah yang diangkat berdasarkan kontra politik, sehingga ada kepala sekolah di Kabupaten Bima Nusa Tenggara Barat dari jabatan Plt kemudian diangkat langsung secara definitif menjadi kepala sekolah tanpa melalui prosedur yang dibuat dalam Permendiknas No.28 Tahun 2010. Selain itu, ada kepala sekolah telah lulus calon kepala sekolah tahun 2007 baru dingkat tahun 2015 tanpa ada alasan logis yang mendasari itu, hanya dikarenakan tidak ikut terlibat dalam mendukung Bupati sehingga nama tidak terkafer untuk dilantik tahun 2015. Praktek politik praktis ini, mulai dirasakan dilingkungan publik ketika dipelopori oleh Bupati yang menjabat pada tahun 2010-2015 untuk masa jabatan tahap kedua.

Temuan di atas sesuai dengan penelitian yang dilakukan oleh Wahiyuddin dengan judul "Politisasi Pejabat Struktural Eselon II di Lingkungan Sekretariat Daerah Kabupaten Muna Sulawesi Tenggara" bahwa Rekrutmen CPNS di Kabupaten Muna menghadapi banyak permasalahan mulai dari penyusunan formasi sampai pengumuman hasil tes. Adanya CPNS 'titipan' dari oknum pejabat menjadi salah satu buktinya. rekrutmen pejabat struktural juga menunjukkan ketidak sesuaian dalam hal kompetensi, profesionalitas dan prestasi kerja pegawai. Rekrutmen tersebut didasarkan pada pertimbangan politik dan uang. Baperjakat berperan memberikan pertimbangan, namun bupatilah yang membuat keputusan akhir. Bupati Kabupaten Muna selama tahun 2005 hingga 2010 merekrut pejabat-pejabat yang berjasa, loyal terhadap bupati, baik secara politis maupun personal, memiliki ikatan emosional dan bisa memberikan kontribusi baik secara politik maupun finansial terhadap Bupati.

\subsubsection{Faktor Pendukung}

Persyaratan yang diatur dalam Permendiknas No.28 Tahun 2010 bagi calon kepala sekolah memiliki kualifikasi S1/DIV, berdasarkan temuan bahwa guru-guru yang mengikuti calon kepala sekolah ada yang berkualifikasi ijasah S2 setiap tahun mengalami penambahan, hal ini menunjukan kompetensi seorang kepala sekolah sangat menentukan oleh kualitas keilmuan sehingga mutu pendidikan akan lebih baik. Sebagaimana yang disampaikan oleh informan 6. untuk sekolah di Kabupaten Bima Nusa Tenggara Barat yang mengusulkan guru-guru yang berkualifikasi S2 untuk mengikuti calon kepala sekolah; untuk sekolah menengah atas terdiri dari; SMA Lambitu, SMA 2 Langgudu, SMA 1 Bolo, SMA 1 Monta, SMA 2 Woha, SMA 1 Woha dan SMA 1 Donggo. Untuk Sekolah Menengah Pertama terdiri dari; SMPN 1 Madapangga, SMP 2 Bolo dan SMP 3 Madapangga. Untuk Sekolah Dasar terdiri dari; SD Kawinda Na'e dan SD 2 Tente.

1.3. Upaya yang dilakukan Mengatasi Hambatan dalam Implementasi Permendiknas No.28 Tahun 2010

Berdasarkan hasil penelitian upaya yang dilakukan Dikpora mengatasi hambatan dari aspek internal yaitu menyesuaikan penerapan Permendiknas No.13 Tahun 2007 dengan Permendiknas No.28 Tahun 2010 dalam proses perekrutan dan pengangkatan kepala sekolah di Kabupaten Bima Nusa Tenggara Barat disebabkan Dikpora belum memahami secara keselurahan isi Permendiknas No.28 tahun 2010 terhadap kondisi SDM yang mengikuti calon kepala sekolah, salah satu isi Permendiknas yang disesuaikan terkait kelengkapan administrasi, panitia perekrutan memberikan keringan kepada calon kepala sekolah yang perlu diajukan oleh calon kepala sekolah hanya Ijazah terakhir dan SK kenaikan pangkat/golongan untuk melengkapi administrasi hal ini juga yang termuat dalam Permendiknas No.13 Tahun 2007. Sedangkan upaya yang dilakukan terkait kekurangan anggaran yang dialokasikan oleh Pemda 
dalam proses perekrutan calon kepala sekolah Dikpora mengajukan kembali permohonan tambahan APBD untuk tahun 2016 ke Pemda.

Upaya mengatasi hambatan pada aspek eksternal dalam pengangkatan kepala sekolah pihak BKD tidak akan mempublikasikan pra pelantikan nama-nama kepala sekolah yang diusulkan untuk dilantik tahun 2015 oleh Bupati, dikhawatirkan ada oknum yang memanfaatkan situasi pemilukada. Sedangkan pengangkatan kepala sekolah oleh Bupati sebagai Plt, upaya yang dilakukan adalah kepala sekolah tersebut tidak ditugaskan pada sekolah yang telah berstatus Negeri, sebagai langkah awal pihak BKD menempatkan pada sekolah SATAP.

Temuan hasil penelitian di atas didukung oleh hasil penelitian yang dilakukan Nurlinah tentang "Relasi Aktor dalam Proses Pengangkatan PNS dalam Jabatan Struktural di Kota Makassar". Hasil penelitiannya mengungkapkan ada beberapa aktor yang terlibat dalam pengangkatan PNS dalam jabatan struktural yaitu diantaranya; Walikota, Tim Baperjakat, Kepala SKPD, dan kepala bidang terkait dengan mutasi pada BKD. Meski demikian, walikota merupakan aktor utama yang memiliki wewenang paling besar dalam menentukan pengangkatan, promosi maupun demosi PNS dalam jabatan struktural.

Berdasarkan Permendiknas No. 28 Tahun 2010 pasal 2 point satu menegaskan seorang kepala sekolah harus memenuhi persyaratan umum dan persyaratan khusus, persyaratan umum mencakup sepuluh poin tidak hanya berkualifikasi ijasah $\mathrm{S} 1$ dan berpangkat/golongan minimal III/c. Hal ini jika dikaitkan dengan hasil penelitian menunjukan adanya sikap toleransi yang menyalahi aturan di mana Dikpora memberikan keringan kepada calon kepala sekolah untuk mengajukan lamaran tanpa harus memenuhi kriteria persyaratan umum yang ditentukan, dengan adanya kebijakan seperti ini akan memicu tumbuhnya solidaritas KKN yang berantai mulai dari perekrutan sampai pangangkatan.

Keberadaan PP no.100/2000 sebagai kebijakan alternatif yang dibuat oleh pemerintah karena dinilai dapat membantu dalam penerapan Permendiknas No.28 tahun 2010 atau kebijakan lainnya sehingga dalam pelaksanaannya akan tepat sasaran dan sesuai dengan rule of law, misalnya ada sekolah yang memiliki tenaga guru yang berstatus Pegawai Negeri Sipil dengan golongan III/b karena pada sekolah tersebut terbatas guru yang PNS maka untuk kelancaran pelaksanaan tugas organisasi seorang Pegawai Negeri Sipil tersebut dapat diangkat sebagai Pelaksana Tugas (Plt) oleh Bupati selaku pimpinan daerah. Pengangkatan kepala sekolah berdasarkan PP No.100 Tahun 2000 yang memberikan kewenangan kepada Bupati untuk menunjuk dan menetapkan seorang guru sebagai pelaksana tugas untuk menjadi kepala sekolah, tidak semestinya berdasarkan unsur kepentingan politik sehingga kompetensi nepotisme menjadi nilai prioritas, namun dengan adanya hak prerogatif lebih mengutamakan kompetensi kuaitas keilmuan seorang yang ditunjuk sebagai Plt dalam menunjang mutu pendidikan yang lebih baik. Bukan berarti karena jabatan Plt tidak definitif sehingga untuk penempatan seseorang yang diberi tugas hanya asalasalan saja dalam hal ini berdasar kehendak pribadi, kepentingan kelompok atau karena imbalan jasa. Perlu disadari bahwa substansi dari PP no.100/2000 yaitu menanggulangi adanya kemandekan dalam pelaksanaan tugas dengan cara menunjuk langsung PNS yang dianggap cakap oleh Pejabat Pembina Kepegawaian (PPK) ataupun Pemerintah daerah yang berkepentingan untuk menjadi kepala sekolah guna memimpin sebuah lembaga pendidikan agar kegiatan dalam organisasi dapat kembali berjalan dengan baik.

\section{KESIMPULAN}

1.1. Proses perekrutan Kepala Sekolah Menengah Pertama di Kabupaten Bima Nusa Tenggara Barat dilakukan melalui empat tahap. Tahap pertama yaitu pengumuman, pengumuman merupakan prosedur penyebaran informasi yang dilakukan oleh Dikpora Kabupaten Bima Nusa Tenggara Barat mengenai penerimaan dan perekrutan calon kepala sekolah baru kesemua institusi 
pendidikan mulai dari SD, SMP, dan SMA malalui pengawas sekolah, dan UPTD disetiap Kecamatan di Kabupaten Bima Nusa Tenggara Barat. Tahap kedua pengusulan oleh kepala sekolah, kepala sekolah mengusulkan nama-nama guru yang diurutkan berdasarkan tugas tambahan disekolah dan berdasarkan kepangkatan/golongan. Tahap ketiga yaitu seleksi administrasi, panitia pelaksana perekrutan calon kepala sekolah melakukan seleksi berkaitan dengan kelengkapan berkas calon kepala sekolah yang mencakup kelengkapan persyaratan umum dan persyaratan khusus. Tahap keempat yaitu pengusulan oleh Dikpora, Pengusulan kepala sekolah yang dilakukan oleh Dikpora Kabupaten Bima Nusa Tenggara Barat melalui dua jalur, yaitu jalur umum dan jalur khusus. Jalur umum yaitu calon kepala sekolah yang diusulkan berdasarkan pengusulan oleh kepala sekolah dan pengawas. Sedangkan jalur khusus yaitu calon kepala sekolah yang langsung ditetapkan oleh Dikpora dan Bupati berdasarkan kinerja yang pernah dilakukan.

1.2. Proses pengangkatan Kepala Sekolah Menengah Pertama di Kabupaten Bima Nusa Tenggara Barat melalui dua cara. Cara pertama berdasarkan Permendiknas No.28 tahun 2010, pelaksanaan diawali dengan penilaian akseptabilitas oleh tim pertimbangan dan ditetapkan oleh Bupati untuk dilantik. Cara kedua berdasarkan Peraturan Pemerintah No.100 tahun 2000, pelaksanaan dilakukan dengan pengangkatan langsung oleh Bupati berdasarkan pertimbangan tertentu yang diberi tugas sebagai Plt kemudian diangkat secara definitif.

1.3. Faktor penghambat dan pendukung penerapan Permendiknas No.28 Tahun 2010 adalah Dikpora belum menerapkan secara keseluruhan isi Permendiknas No.28 Tahun 2010 disebabkan belum bisa disesuaikan dengan kondisi dilapangan mengingat SDM calon kepala sekolah banyak yang belum memenuhi kualifikasi, selain itu pengangkatan kepala sekolah secara definitif maupun sebagai pelaksana tugas (Plt) adanya nuansa politik yang dilakukan oleh Bupati. Faktor pendukung meningkatnya antusias dari para guru yang berkualifikasi ijasah S2 untuk mengajukan diri mengikuti cakep setiap tahun.

1.4. Upaya yang dilakukan mengatasi hambatan dalam implementasi Permendiknas No.28 Tahun 2010, Dikpora menyesuaikan penerapan Permendiknas No.28 Tahun 2010 dengan Permendiknas No.13 Tahun 2007 dalam proses perekrutan dan pengangkatan kepala sekolah di Kabupaten Bima Nusa Tenggara Barat dengan memberikan keringan kepada calon kepala sekolah dalam melengkapi administrasi pengajuan calon kepala sekolah. Upaya yang dilakukan terhadap pengangkatan kepala sekolah yang ditunjuk langsung oleh Bupati yang berstatus Plt, tidak ditugaskan menjadi kepala sekolah yang telah berstatus Negeri, sebagai langkah awal pihak BKD menempatkan pada sekolah SATAP.

\section{REKOMENDASI}

2.1. Proses perekrutan kepala sekolah alangkah baiknya tidak membatasi hanya pada tugas tambahan sebagai Wakil Kepala Sekolah atau Wakepala sekolah Urusan, namun diberlakukan sacara menyeluruh pada guru-guru yang memenuhi persyaratan walaupun tidak diberi tugas tambahan.

2.2. Proses pengangkatan kepala sekolah dengan keterlibatan tim pertimbangan perlu ditingkatkan agar dapat menghilangkan sikap KKN dari pihak birokrasi karena akan berdampak buruk pada mutu pendidikan.

2.3. Keterlibatan pemerintah daerah dalam insitusi pendidikan yang bersifat prinsipil perlu dikurangi mengingat akan menurunkan kepercayaan publik terhadap pendidikan.

2.4. Perlu adanya efektifitas dalam pelaksanaan fungsi koordinasi antara Dikpora Provinsi NTB dengan Dikpora Kabupaten Bima Nusa Tenggara Barat dalam penerapan Permendiknas No.28 
Terakreditasi Peringkat 5 (No. SK: 85/M/KPT/2020)

Tahun 2010 agar memperoleh pemahaman yang sama dalam pelaksanaanya dengan langkah melakukan sosialisasi oleh Dikpora Provinsi. Selain itu, Proses pengangkatan dan pemindahan pejabat struktural berpedoman pada prinsip the right man in the right place and the right man in the right job, memperhatikan prestasi kerja dan disiplin, sehingga pengangkatan dan pemindahan pejabat struktural berdasarkan kebutuhan organisasi dan merupakan upaya untuk mewujudkan good governance (Wahiyudin, 2014).

\section{DAFTAR PUSTAKA}

Afriyani P, (2013). Pelaksanaan Tugas Guru Profesional di Sekolah Menengah Atas Negeri Kota Pariaman. Jurnal Administrasi Pendidikan Volume 1, No. 1, 376-461 Ajadan S, (2015). Evaluasi Program Pendidikan dan Pelatihan Calon Kepala Sekolah (Studi Evaluasi Pascadiklat di LPMP Provinsi Maluku Utara). Jurnal Teknologi Pendidikan Volume. 17, No. 3, 164-175.

Baihaqi, Khairuddin, Husen, (2012). Sistem rekrutmen, seleksi dan penempatan Kepala Sekolah Menengah Pertama Negeri Pada dinas pendidikan kota banda aceh. Jurnal Administrasi Pendidikan Volume 1, No.1 Hal. 14-28.

Baswedan A, (2014). Paparan Menteri Pendidikan dan Kebudayaan "Gawat Darurat Pendidikan di Indonesia". Jakarta.

Bhirowaty H, (2014). Analisis kebijakan pengangkatan Kepala Sekolah Dasar Muhammadiyah di lingkungan PDM Kota Malang.

William. (1996). The Human Resource Function In Educational Administration. New Jersey : Prantice Hall, Inc

Faisal, (2013). Implementasi Permendiknas Nomor 28 Tahun 2010 Di Kabupaten Sambas. Jurnal visi ilmu pendidikan halaman 1061.

Ghufron A. (2014). Analisis Kebijakan Pemenuhan Beban Kerja Guru SMA Negeri 2 Kota Tarakan.
Hartanto S.(2014). Good procedures or new ways of preparing principals Indonesia.

Hidayat A (2011). Pengaruh Pelaksanaan Rekrutmen Dan Seleksi Kepala Sekolah Terhadap Kinerja Kepala SMP Dan SMA PGRI Sekabupaten Dan Kota Bandung.

Irianto P (2014). Evaluasi Model Rekrutmen Kepala Sekolah di Surakarta. Naskah Publikasi.

Jamali Y. (2016). Evaluasi Of Recruitment Policy Implementation Head Of The State High School in Banda Aceh. Jurnal Ilmiah Education Managent Volume 6, No.2.

Lembaga Pengembangan Dan Pemberdayaan Kepala Sekolah. (2011). Petunjuk Pelaksanaan Rekrutmen Calon Kepala Sekolah/Madrasah.

Maisaroh S. (2015). Lelang Jabatan Kepala Sekolah Dan KualitasLayanan Pendidikan (Studi Kasus pada 2 Sekolah Menengah Atas Negeri di Jakarta Selatan). Jurnal Administrasi Publik (JAP), Vol. 3, No. 11, Hal. 1917-1923

Manap, Hartuti, Djuwita, Komarudin, Alperi, (2010). Pemetaan Kompetensi Kepala Sekolah SMP di Provinsi Bengkulu Dalam Rangka Peningkatan Kompetensi Berkelanjutan. Jurnal Ilmiah Manajemen Pendidikan Volumen 4, No. 5, 1-103.

Muliati A (2013). Program penyiapan calon kepala sekolah Melalui seleksi akademik dan diklat.

Mulyasa, Enco. (2003). Menjadi Kepala Sekolah Profesional, Bandung: Remaja Rosdakarya.

Nuh. (2010, 03 November). Kemendiknas Atur Mutasi Kepala sekolah. Diakses pada tanggal 25 Juni 2016, dari: jpnn.com/news/kemendiknas-aturmutasi-kepala sekolah.

Nurlinah, 2016. Nuansa politisasi dalam pelaksanaan tugas guru Sebagai dampak dari desentralisasi pendidikan. Jurnal Ilmu Pemerintahan, Volume 9 (1), hal.49-62.

Nurbaya, Harun, Djailani, (2015). Gaya Kepemimpinan Kepala Sekolah 
Dalam Meningkatkan Kinerja Guru Pada SD Negeri Lambaro Angan. Jurnal Administrasi Pendidikan Volume 3, No. 2. Hal. 116 - 127.

Patimah S.(2015).Pengaruh Rekrutmen Dan Seleksi Terhadap Kinerja Kepala Madrasah Ibtidaiyah Negeri (MIN) Sekota Bandar Lampung. Jurnal ilmiah Peuradeun ISSN: 2338-8617

Peraturan Menteri Pendidikan Nasional No. 28 Tahun 2010 tentang penugasan guru sebagai kepala sekolah/madrasah.

Peraturan Pemerintah Republik Indonesia, Nomor 74 Tahun 2008 tentang Guru.

Peraturan Menteri Negara Pendayagunaan Aparatur Negara Dan Reformasi Birokrasi Nomor 16 Tah U N 2009 Tentang Tentang Jabatan Fungsional Guru Dan Angka Kreditnya.

Rahmawiati E, dkk. (2009). Pendelegasian Wewenang dalam Sistem Manajemen PNS di Indonesia. Jakarta: Pusat Kajian Kinerja Sumber Daya Aparatur. Lembaga Administrasi Negara.

Ritonga \& Lestari, S (2012). Perencanaan Sistem Pendukung Keputusan Pengangkatan Calon Kepala Sekolah Negeri Bandar Lampung dengan Metode SAW. Jurnal Informatika Volume. 12, No. 2, 172-179.

Sugiyono, (2015). Metode Penelitian Kuantitatif Kualitatif dan $R \& D$. Bandung: Alfabeta

Sudarsono, (2010). Jabatan Fungsional Guru dan Angka Kreditnya.

Turmizi. (2015, 08 Oktober). Pengembangan kompetensi guru melalui pelaksaan tugas dan tanggung jawab secara profesional. Diakses pada tanggal 25 Juni 2016, dari: www.kompasiana.com/ahmadturmizi/ Pengembangan-kompetensi-gurumelalui-pelaksaan-tugas-dantanggung-jawab-secara-profesional.

Trisulawati N (2012). Implementasi Kebijakan Pengangkatan Tenaga Honorer di Dinas Pendidikan Kabupaten Magetan, Tesis S-2 Magister Administrasi Publik, Universitas Sebelas Maret Surakarta
Wahjosumidjo, (2008). Kepemimpinan Kepala Sekolah: Tinjauan Teoretik dan Permasalahannya. Jakarta: Rajawali Pers

Wasitohadi, (2016). Kolaborasi dan sinergi antar lembaga Dalam peningkatan kompetensi kepala sekolah. Jurnal Managen Pendidikan, Volume. 3, No. 2, 230-245.

Wahiyuddin, 2014. Politisasi Pejabat Struktural Eselon II di Lingkungan Sekretariat Daerah Kabupaten Muna Sulawesi Tenggara. Jurnal Kebijakan \& Administrasi Publik, Volume, 18 Nomot (1), hal (53-65). 